\title{
Efektivitas Tahfidh dan Tahsin Al-Quran pada Masyarakat di Indonesia
}

\author{
${ }^{1 *}$ Nadia Saphira Cahyani, ${ }^{2}$ Neila Sakinah, ${ }^{3}$ Nur Nafisatul Fithriyah \\ 1,2,3 Tazkia IIBS Malang, Indonesia
}

\begin{abstract}
Artikel ini ingin menunjukkan asal mula munculnya tahfidz Alquran di Indonesia, korelasi antara tahfidz dan tahsin, serta efektivitas anatara tahfidz dan tahsin di Indonesia. Dengan berbagai metode tahfidz dan tahsin yang ada di Indonesia, penulis mencoba menganalisis metode mana yang cocok dan sesuai untuk diterapkan kepada masyarakat Indonesia untuk mengoptimalkan dan memaksimalkan dalam menghafal Alquran. Selain itu metode tahfidz juga diperlukan untuk menunjang kelancaran dan memudahkan dalam menghafal. Metode yang digunakan dalam artikel ini yaitu metode historis, dengan mengkorelasikan antara metode awal hafalan di Indonesia dengan yang digunakan pada saat ini. Metode historis juga dapat memberikan pemaparan dari para Kiai atau masyarakat Indondesia yang terlibat dalam awal mula menghafal Alquran. Kemudian dapat ditarik untuk dianalisis dengan metode menghafal Alquran yang ada pada saat ini. Analisis dari penulis menghasilkan bahwa tahfidz dan tahsin merupakan dua elemen yang tidak dapat dipisahkan. Keduanya harus berjalan secara beriringan dengan tujuan agar mendapatkan hasil yang maksimal dan mendapat kesempurnaan dalam bacaan maupun menghafal Alquran.
\end{abstract}

Keywords: Tahfidz, Tahsin, Histori, Efektivitas

\section{Latar belakang}

Al-qur'an merupakan kitab suci umat Islam. Mengajarkan Al-qur'an bisa dilakukan melalui membaca, menulis dan menghafal. (Awwaliyah: 10, 2019). Menghafal Al-qur'an (tahfidz Al-qur'an) merupakan bentuk interaksi umat Islam dengan Al-qur'an yang sudah diterapkan secara turun-menurun sejak diturukan kepada nabi Muhammad hingga zaman sekarang dan sampai masa yang akan datang. Umat Islam diberikan kemudahan oleh Allah dalam menghafal Al-qur'an baik yang berasal dari Arab maupun non Arab, baik yang mengerti atau tidak mengerti arti dari kata-kata $\mathrm{Al}$ qur'an. (Aida: 52, 2017).

Keberlangsungan aktifitas tahfidz Al-qur'an hingga saat ini terus berjalan.
Bahkan bisa dikatakan semakin mapan. Pusat pendidikan keislaman di berbagai belahan dunia bahkan memiliki kegiatan utama tahfidz Al-qur'an. Tidak jauh berbeda, kini masyarakat muslim Indonesia juga mulai menyemarakkan kegiatan tahfidz Al-qur'an.

Masyarakat muslim Indonesia tidak serta merta seluruhnya mengaji Alqur'an dengan cara menghafal, namun sebelumnya ada yang melaluinya dengan tahsin, yang memiliki tahapan tartil atau membaca Al-qur'an dengan tempo teratur dengan melihat Al-qur'an, dengan tujuan lebih mendalami dan memahami isi kandungan Al-qur'an yang dibaca.

Ada sekian banyak proses kegiatan dalam tahfidz Al-qur'an. Diantaranya adalah menambah materi 
hafalan baru, murajaah (mengulang) hafalan, dan munaqasah (ujian) melalui uji kelancaran tasmi'ul quran, yaitu membaca secara bil ghaib dengan ketentuan sekian juz.

Meningkatnya minat masyarakat muslim Indonesia untuk menghafalkan Al-qur'an telah menarik perhatian banyak peneliti. Namun, saat ini peneliti memiliki fokus kajian terhadap bagaimana bistory atau sejarah munculnya tahfidz $\mathrm{Al}$-qur'an di kalangan masyarakat Indonesia, bagaimana korelasi antara tahsin dan tahfidz pada masyarakat muslim Indonesia, dan efektivitas tahsin dan tahfidz pada masyarakat muslim Indonesia saat ini.

\section{Sejarah Tahfidz Al-qur'an di Indonesia}

Tradisi tahfidz Al-qur'an di Indonesia berawal dari alumni Timur tengah yang sedang menuntut ilmu di Timur Tengah. Seiring berkembangnya zaman, kegiatan tahfidz Al-qur'an tersebut semakin berkembang, bahkan populer. Para Ulama melakukan pembelajaran tahfidz Al-qur'an dari sanad Timur Tengah dengan cara talaqqi dan musyafahah. Beberapa lembaga yang telah ditunjuk dapat melakukan pembelajaran tahfidz Al-qur'an, atau dapat juga dipelajari secara pribadi. Ulama penghafal Al-qur'an di Indonesia dianataranya, Kiai Haji Mnawwir (Krapyak), Kiai Haji Munawwar (Gresik), Kiai Haji Sa’id Ismail (Madura). (Ali, 144: 2019)

Lembaga tahfidz Al-qur'an biasanya berupa asrama yang terdapat juga sekolah didalamnya. Para sntri didampingi oleh Kiai yang mendidik dan mengajar, para santri dapat melaksanakan pembelajaran di masjid atau aula yang telah disediakan.
Memang tradisi tahfidz Al-qur'an telah banyak diminati, namun hingga tahun 1970-an lembaga tahfidz terbatas pada beberapa daerah di Indonesia. Hingga pada akhirnya setelah tahfidz Alqur'an masuk dalam Musabaqah Tilawatil Quran atau biasa disebut dengan MTQ. Pada tahun 1981 MTQ bermunculan di banyak daerah di Indonesia. Kurang lebih ada 6.044 nama dengan alamat serta pondok pesantren potensial di Indonesia pada tahun 2005 .

Tidak hanya setara asrama lembaga, ada juga lembaga tahfidz Alqur'an berupa perguruan tinggi tahfidz dan sekolah asrama. Asrama berbentuk perguruan tinggi tersebut, yaitu PTIQ dan IIQ. Keduanya merupan institusi yang menggabungkan perguruan tinggi tahfidz Al-qur'an dan sekolah asrama.

Ada tiga model lembaga tahfidz Al-qur'an di Indonesia menurut laporan Pelatihan dan Badan Pengembangan Depag Indonesia. Pertama, sekolah asrama khusus yang hanya memberikan program tahfidz Al-qur'an; seperti Yanbuul Quran Kudus. Hingga saat ini, pondok pesantren tersebut hanya fokus pada program menghafal saja sebagai cita-cita dari Kiai Haji Arwani Amin. Kedua, sanad tahfidz Al-qur'an. Pada umumnya asrama tahfidz memiliki sanad yang secara silsilah diurutkan dari nabi Muhammad ke guru tahfidz yang ada. Namun, di Indonesia semua sanad tahfidz Al-qur'an bersumber dari Makkah melalui para Kiai berikut: Kiai Haji Muhammad Sa'id bin Ismail (Sampang), Kiai Haji Munawwir (Krapyak), Kiai Haji Munawwar (Gresik), Kiai Muhammad Mahfudz at Tarsami (Pacitan) dan Kiai Haji Dahlan M. Khalil (Jombang).

Ketiga, mengadopsi metode atau cara menghafal Al-qur'an sebagai berikut: (Ahmad: 15, 97). 
1. Ngeloh/Saba'/nyetor,yaitu membaca ayat Al-qur'an yang telah dihafal sesuai dengan seberapa banyak kesepakatan ayat yang akan disetorkan kepada guru atau kiainya.

2. Murajaah, yaitu mengulang hafalan sebelumnya yang telah disetorkan kepada guru atau Kiai. Biasanya 1/4 juz dari 1 juz yang telah dihafalkan sebelumnya atau bisa lebih sebatas halaman terakhir yang telah dihafal.

3. Sima'an, yaitu kegiatan yang dilakukan secara berkelompok. Satu orang membaca tanpa melihat Alqur'an, yang lainnya mendengarkan dan membenarkan jika ada bacaan yang salah.

Selanjutnya, dalam proses menghafal, biasanya para santri memiliki satu mushaf tertentu. Umumnya, asrama tahfidz menggunakan Al-qur'an pojok. Secara karakteristik, setiap pojok berkahir dengan waqaf dan terdiri dari 15 baris.

Ada beberapa hal yang perlu diperhatikan dalam menghafal Al-qur'an, yaitu pihak asrama tahfidz menekankan pentingnya persiapan fisik dan mental santri. Persiapan dilakukan dengan tekun, kerja keras, fokus dan konsentrasi, menahan diri dari kegiatan yang kurang bermanfaat, serta meninggalkan sifatsifat yang tidak bermoral. Selain itu harus intensif dalam beribadah, misalnya shalat malam (qiyamul lail) dan puasa sunnah.

\section{Tahfidz Al-qur'an}

Tahfidz Al-qur'an terdiri dari dua kata, tahfidz dan Al-qur'an. Tahfidz sendiri berasal dari bahasa Arab yang berarti hafidza-yahfadzu-bifdzan yang berarti menjaga, menghafal. (al Raghib, 164: tt) Dalam kitab al-Mufrada $>t$ fi $>$ Ghara $>$ ib Al-qur'an, definisi menghafal yakni proses mengulang sesuatu baik dilakukan dengan membaca ataupun mendengar. Suatu pekerjaan yang jika dilakukan secara berulang-ulang seseorang akan hafal dengan pekerjaan tersebut.

Dalam Fenomena ini bisa di petakkan antara peminat pengkaji $\mathrm{Al}$ qur'an dengan fenomena banyaknya penghafal Al-qur'an di Indonesia. Pertama, pengkaji Al-qur'an yang memposisikan bahwa Al-qur'an merupakan teks mulia sekaligus ia mengkaji teks Al-qur'an secara kritis, untuk keperluan menggali makna di dalamnya. Kelompok ini akan terus menggali makna di dalam Al-qur'an dan bisa jadi mengkomparasikan dengan mencari metodologi terbaru dalam memahami Al-qur'an melalui keilmuan modern seperti sastra, bahasa, filsafat, sosiologi dan lain-lain.

Kedua, merupakan kelompok pengkaji Al-qur'an yang memnadang bahwa hafal Al-qur'an sebagai tujuan. Orientasi mereka adalah target, bukan lagi proses. Maka yang paling dicari oleh kelompok ini adalah bagaimana cara agar dapat hatam dengan cepat, memiliki hafalan yang kuat dan sebagainya. Tidak terfikirkan oleh mereka, bagaimana metodologi pemahaman Al-qur'an dalam rangka menyelesaikan problematika zaman yang terus bermunculan. Golongan ini memiliki beberapa tingkatan, ada sebagian mereka yang menghafal tanpa perbekalan ilmu tajwid terlebih dahulu, lalu memutuskan untuk menghafal Al-qur'an. Ada Sebagian yang lain yang sudah berbekal ilmu tajwid lalu menghhafalkan Al-qur'an. (Ali, 14: 2015).

Ketiga, Pengkaji Al-qur'an yang menyadari bahwa Al-qur'an sebagai firman Allah yang ketika seseorang membacanya, maka pahala akan 
didapatkan olehnya. (al-Muta'abad bitila>watihi). Mereka juga mengkaji Alqur'an secara kritis tetapi juga tidak menjadikan hafal Al-qur'an sebagai orientasi akhir.Keteguhan mereka yakni menjadikan Al-qur'an sebagai bentuk ibadah. (Ali, 14: 2015).

Tahfidz Al-qur'an memiliki beberapa metode, diantaranya yaitu metode Thariqah Tsalsuli, metode Thariqah Jam'i, dan metode Thariqah Muqassam. (Moh. Fathurrozi, 2019).

1. Metode Thariqah Tasalsuli

Metode ini diawali dengan menghafal satu ayat pertama, setelah hafal kemudian dilanjutkan ke ayat kedua. Untuk lanjut ke ayat ketiga dan berikutnya, maka harus mengulang hafalan dari ayat pertama, kedua, dan seterusnya hingga ayat terakhir yang ditargetkan.

\section{Metode Thariqah Jam’i}

Berbeda dengan metode Thariqah Tasalsuli, metode ini diawali dengan menghafal per ayat hingga akhir ayat yang ditargetkan. Setelah sampai pada target hafalan, kemudian hafalan tersebut digabungkan dan diulang dari ayat awal yang dihafal hingga akhir ayat yang ditagetkan.

\section{Metode Thariqah Muqassam}

Metode ini membagi bagian hafalan sesuai dengan kelompok tema dan maknanya. Kemudian menuliskan hafalannya tersebut kedalam kertas, dan memberi sub judul pada setiap bagian yang dihafalkan. Kemudian dihafalkan secara komulatif dan digabungkan.

\section{Tahsin Al-qur'an}

Tahsin merupakan tata cara membaca Al-qur'an dengan memperhatikan kaidah tajwid dengan baik dan benar. Ali Muntahar menjaelakan, makna tahsin adalah "tahsin" sama dengan makna tajwid yakni perbaikan, penyempurnaan. Artinya makna tahsin lebih luas daripada tajwid, dikarenakan dalam tahsin disamping menggunakan kaidah-kaidah yang terdapat dalam ilmu tajwid, ia juga berusaha memperindah bacaan dengan suara yang merdu. Dengan melaksanakan kegiatan tahsin, maka didalamnya juga mengandung pelajaran tajwid. (Safrina dan Realita, 118: 2015).

Metode Tartil berasal dari kata rațala yang berarti serasi dan indah. Maksudnya yaitu mengucapkan kalimat dengan baik dan benar serat disusun dengan rapi. Metode at-Tartil berasal dari inisiatif dari Tim pembina TPQ lembaga ma'arif NU yang ada di Sidoarjo. Adanya metode ini dilatarbelakangi oleh keresahan yang dialami oleh ulama-ulama syuriah NU pada tahun 80-90 an tentang banyaknya buku panduan untuk belajar Al-qur'an namun tidak dibarengi dengan ketermapilan dari para ustadz dan ustadzah dalam mengoperasikan buku panduan tersebut. (Rumainur, 3 : 2019).

Ulama NU yang dimaksud yaitu Ir.Imam Syafi'i yang pada saat itu menjabat sebagai ketua biro TPQ LP Ma'arif Cabang Sidoarjo yang juga dibantu oleh tim yaitu ustadz Fahruddin Sholih, Masykur Idris dan Suwarno H.B, untuk membuat buku panduan BTQ yang lebih mudah untuk dipelajari oleh para santrinya. Metode ini menggunakan cara yang praktis, sedikit demi sedikit dikenal dengan CBSA (cara belajar santri 
aktif) yaitu waspada pada bacaan yang salah serta menggunakan metode drill.

Adapun macam-macam metode tahsin diantaranya, yaitu metode Ummi. Metode ini dinamakan metode ummi yang dinisbatkan pada nama ibu, dengan harapan para pembelajar akan senantiasa menghormati dan mengingat jasa ibu.

\section{Tranformasi Tahfidz Al-qur'an}

\section{di Indonesia}

Seiring berjalannya waktu, kegitan pengkajian tahfidz Al-qur'an semakin hari semakin berkembang dengan baik. Salah satunya yaitu adanya program MTQ yang bertujuan membumikan Alqur'an. Namun, tidak semua pengahfal Al-qur'an berpartisipasi dalam kegiatan tersebut dengan anggapan bahwa kegiatan tersebut merupakan hal yang sama dengan memperjual belikan Alqur'an. Pertanyaan tersebut berdasarkan apa yang ada dalam kitab al-Mursyid alWajiz fi ilmi al-Quran al-Aziz yang dipelajari oleh Kiai Munawwir Krapyak.

Adapun pesantren yang memperbolehkan kegitan MTQ akan mengirimkan delegasi peserta untuk bersaing dengan peserta lainnya dimulai dari tingkat kecamatan hingga nasional. Dengan harapan Al-qur'an dapat menjadi semangat dan motivasi tidak lain dalam rangka hanya mengharap ridho Allah SWT.

Namun, MTQ tidak serta merta menjadikan penghafal Al-qur'an lancar dalam menghafal. Ada satu proses yang tidak dapat ditinggalkan sebelum dan ketika dalam proses menghafal Al-qur'an, yaitu tahsin. Dengan berbagai metode dalam proses tahsin, para penghafal Alqur'an dapat dipastikan lebih mudah menambah dan mengulang hafalan yang telah dicapai selama ini. Banyaknya metode tahsin juga mempermudah dalam menerapkan ilmu tajwid dalam memperindah Al-qur'an.

Adapun metode menghafal yang dapat digunakan bersamaan dengan metode tahsin, misalnya metode tabarak. Metode dengan cara mendengar dan menirukan tersebut, tidak dapat digunakan oleh semua umur, melainkan hanya akan efektif jika digunakan oleh anak-anak dikarenakan anak-anak memiliki daya konsentrasi yang pendek.

Selanjutnya, metode Tasalsuli yaitu metode dengan cara menghafalkan satu ayat terlebih dahulu, kemudian dilanjutkan ke ayat kedua. Untuk menambah ayat berikutnya diulang lagi dari ayat pertama dan kedua, baru beranjak ke ayat ketiga dan seterusnya. Selain itu ada juga metode Jam'i yaitu menghafalkan ayat per ayat sampai hafal hingga ayat yang ditargetkan. Kemudian dihafalkan kembali gabungan ayat yang telah dihafalkan dari awal sampi batas akhir ayat yang ditargetkan.

Kedua metode ini tidak dapat terlaksana secara efektif dan maksimal jika tidak berjalan beriringan. Sehingga para penghafal Al-qur'an sangat disarankan untuk belajar tashin sebelum menghafal Al-qur'an terlalu jauh, dengan tujuan ada keseimbangan antara keduanya untuk mencapai kesempurnaan menghafal Al-qur'an.

\section{Kesimpulan}

Tahfidz dan tahsin merupakan dua elemen yang tidak dapat dipisahkan. Keduanya harus berjalan secara beriringan dengan tujuan agar mendapatkan hasil yang maksimal dan mendapat kesempurnaan dalam bacaan maupun menghafal Al-qur'an. 
Melihat sejarah menghafal Alqur'an, tidak dapat dipungkiri bahwa menghafal Al-qur'an tidak dapat digapai seperti mebalikkan telapak tangan. Sebab untuk mendapatkan lebel umat terbaik, dibutuhkan kesungguhan dan pengorbanan jiwa dan raga. Untuk mendapatkan hasilkan maka, metodemetode tahsin dan tahfidz Al-qur'an yang ada tidak dapat ditinggalkan.

\section{References}

Al-Ra $>$ ghib al-As $\}$ fiha $>$ ni (tt), alMufroda>t fi> Ghara>ib Al-qur'an, Maktabah Nizar Musthafa al-Ba>z.

Ahmad Abdurrahman (1997), Pedoman Menghayati dan Menghafal Alqur'an, Hadi Press, Jakarta.

Aida Hidayah, (2017), "Metode Tahfidz al-Qur'an untuk anak usia dini (kajian atas buku rahasia sukses 3 hafidz qur'an cilik mengguncang dunia)", Jurnal Studi Ilmu-ilmu alQur'an dan hadis, Vol.18, No.1, hal. 52, Yogyakata.

Ali Romdhoni (2019), "Model Evaluasi Pembelajaran Tahfidzul Qur'an Berbasis Coin Pro 2 (Studi Komparasi Pembelajaran Tahfidz di Turki, Malaysia, dan Indonesia)“, Jurnal Pendidikan Agama Islam , vol.3, No2, hal. 144,

Probolinggo

Ali Romdhoni (2015), “Tradisi Hafalan Qur'an di Masyarakat Muslim Indonesia", Journal of Qur'a>n and $H$ \{adi $>$ th Studies, vol.4, No1, hal. 14, Probolinggo.

Awwaliyah Mursyida, dkk. (2019), "Metode menghafal al-Qur'an pada anak usia dini di tahfidz center darul hufadz kota padang", Journal on early childhood, Vol 2 (2), hal. 10, Padang.

Rumainur (2019), "Efektivitas Metode at-Tartil dalam Pembelajaran
Tahsin Al-qur'an Mahasiwa Perguruan Tinggi Keagamaan Islam di Kalimantan Timur", Fenomena, Vol.11, No 1, hal.3, Samarinda.

Safrina dan Realita (2015), "Program Bengkel Mengaji (Upaya Peningkatan Kemampuan Tahsin Al-qur'an Mahasiswa PAI)", Jurnal Mudarrisuna, Vol. 5, No. 1, hal. 118, Aceh.

Moh. Fathurrozi (2019), "Ini Langkah danMetode Menghafal Al-qur'an yang Tepat" $\underline{\text { http://islam.nu.or.id//, }}$ diakses pada Kamis, 10 Desember 2020, pukul 20.05 WIB. 